\title{
Evaluation of in vitro antioxidative, cytotoxic and apoptotic activities of $R$ heum ribes ethyl acetate extracts
}

\author{
Pembegul Uyar ${ }^{1}$, Nursen Coruh ${ }^{2}$, Mesude İscan ${ }^{3}$ \\ ${ }^{1}$ Department of Biology, Selçuk Üniversity, Konya, Turkey \\ ${ }^{2}$ Department of Chemistry, Middle East Technical University, Ankara, Turkey \\ ${ }^{3}$ Department of Biology, Middle East Technical University, Ankara, Turkey
}

Email address:

pembeguluyar@gmail.com (P. Uyar)

\section{To cite this article:}

Pembegul Uyar, Nursen Coruh, Mesude İscan. Evaluation of in Vitro Antioxidative, Cytotoxic and Apoptotic Activities of Rheum ribes Ethyl Acetate Extracts. Journal of Plant Sciences. Vol. 2, No. 6, 2014, pp. 339-346. doi: 10.11648/j.jps.20140206.22

\begin{abstract}
Rheum species are medicinally important plants due to the presence of anthracene derivatives. This study was designed to determine the antioxidative, cytotoxic and apoptotic properties of Rheum ribes shoot and root ethyl acetate extracts using human promyelocytic leukemia (HL-60) cell line as a model system. R. ribes shoot and root dry powder samples were prepared and extracted with ethyl acetate. The extracts were revealed to be a potential scavenger of DPPH radicals $\left(\mathrm{IC}_{50}\right.$ value of $206.28 \mu \mathrm{g} / \mathrm{ml}$ for shoot and $10.92 \mu \mathrm{g} / \mathrm{ml}$ for root) and the chemical composition of the extracts was quantified by colorimetric determination of total phenol (GAE) and flavonoid (CAE) contents. HL-60 cells were cultured in the presence of various concentrations of extracts up to $72 \mathrm{~h}$. R. ribes inhibited the survival of HL-60 cells in a concentration- and timedependent manner, shown by XTT assay. R. ribes caused HL-60 cells apoptosis via formation of phosphatidylserine externalization, as evidenced by flow cytometry. Exposure of HL-60 cells to higher concentrations of extracts for $72 \mathrm{~h}$ resulted in a shift of $87 \%$ of the cell population from normal to the early/late apoptotic stage. These findings suggest that Rheum ribes ethyl acetate root extracts exhibits potential antioxidant and cytotoxic properties against HL-60 cells better than shoot extracts and exert their toxicity via induction of apoptosis.
\end{abstract}

Keywords: Rheum ribes, Antioxidant, HL-60, Cytotoxicity, Apoptosis

\section{Introduction}

Natural products are of great importance in the drug discovery process, particularly in the areas of cancer. The screening with innovative biological assays allows the verification of their active principle. These improvements provided the basis for rational drug discovery and have fundamentally contributed to the development of important pharmaceuticals of natural origin.

Rheum species has anthracene derivatives found in the subterranean parts of the plant which makes them medicinally important. Rheum ribes L. (Polygonaceae) is used to obtain a component of most important crude drugs in the Middle East (Kashiwada, 1988). Rheum ribes L. (Polygonaceae) is grown mostly in Iran, Lebanon and Eastern Turkey (Shokravi, 1997). Rheum ribes L. is cultivated in some temperate countries for its edible red leaf stalks and a perennial. "Işkın, uşgun or, uçgun" are the local names of $R$. ribes. (Shokravi, 1997).
$R$. ribes (young shoots and petioles) is used against diarrhea and also stomachic and antiemetic as well as against hemorrhoids, measles, smallpox and cholagogue (Baytop, 1999). Fresh stems and petioles of Rheum ribes are consumed as vegetable, and used as digestive and appetizer in Eastern Turkey, while the roots are used to treat diabetes, hypertension, obesity, ulcer, diarrhea and as antihelmintic and expectorant (Abu-Irmaileh, 2003; Tabata, 1994). R. ribes decoction root extracts showed significant blood sugar lowering activity in alloxan-induced diabetic mice, although this extract did not show hypoglycemic action in healthy mice. The antioxidant activity of chloroform and methanol extract of roots and stems of $R$. ribes L. were also studied. (Ozturk, 2007)

Flavonoids, stilbenes and anthraquinones are the major phenolic constituents of Rheum ribes to provide a potential source of antioxidants. The pharmaceutically relevant 
compounds in rhubarb are mainly anthraquinone derivatives, including emodin, rhein, aloe-emodin, physcion, chrysophanol and their glucosides. Among these anthraquinones, emodin has been under intensive investigations since last decade, and it has been shown that emodin possesses a number of biological activities. Some chemicals that occur naturally in plants have begun to receive much attention as safe antioxidants, as they have been consumed by people and animals for years (Namiki, 1990). Therefore, considering the phenolic constituent profile of $R$. ribes, they appeared to provide a potential source of antioxidants, which have well known pharmacological actions such as free radical scavenging, chemoprevention and tumor suppression.

Currently, Rheum ribes its toxicity, pharmaceutical potentials and molecular mechanisms have not been well investigated. We report here the potential of Rheum ribes antioxidant, cytotoxic and apoptotic effects against human promyelotic leukemia (HL-60) cells.

\section{Materials and Methods}

\subsection{Plant Material}

Rheum ribes roots and young shoots were collected from Van, Turkey. The plants were placed on filter papers, and dried under airflow at room temperature in the dark prior to use and analysis. Dry plants were powdered by Waring (model 32BL80) commercial blender at a high speed for at least $2 \mathrm{~min}$ and stored in dark bottles, at room temperature, $25^{\circ} \mathrm{C}$ until use.

\subsection{Preparation of Plant Extracts}

Rheum ribes shoot and root dry powder samples (30 g) were separately dissolved in ethyl acetate (EtOAc) at a ratio of 1:12 (w/v). The samples were extracted by sonicating for 1 $\mathrm{h}$ in a bath sonicator (Bandelin Sonorex Model RK $100 \mathrm{H}$, Berlin, Germany) followed by incubation at $50{ }^{\circ} \mathrm{C}$ on a rotational incubator at $150 \mathrm{rpm}$ for $24 \mathrm{~h}$. Then extracts were filtered through a coarse filter paper on a Büchner funnel and dried in a rotary evaporator at around $40{ }^{\circ} \mathrm{C}$ (Heidolph Laborota 4000) and lyophilizator (Maxi Dry Lyo HetoHolten, Allerod, Denmark). The freeze-dried extracts were kept at $-20{ }^{\circ} \mathrm{C}$ in the dark.

Freeze-dried extracts were named as follows; ethyl acetate shoot extract (ASE) and root extract (ARE).

\subsection{Determination of in vitro Antioxidant Activity, DPPH Method}

DPPH (2,2-Diphenyl-1-picrylhydrazyl) method was applied as proposed by Blois (1958) for determining the free radical scavenging activities of extracts and adapted for 96well microplate reader measurements. DPPH is the purplecolored stable free radical that is reduced into the yellow colored diphenylpicryl hydrazine compound by subtracting hydrogen from the phenolic compounds found in extracts.
Rheum ribes extracts prepared in ethyl acetate were prepared as serial dilutions, ranging from $1333.33 \mu \mathrm{g} / \mathrm{ml}$ to $2.60 \mu \mathrm{g} / \mathrm{ml}$. The assay was conducted in triplicate. Aliquots of $20 \mu \mathrm{l}$ of plant extract prepared in methanol were plated out, to which $280 \mu 1$ of DPPH $\left(1.5 \times 10^{-4} \mathrm{M}\right)$, prepared in methanol was added to the wells. Plates were then tightly covered with lid and aluminum foil to prevent evaporation and were shaken for $2 \mathrm{~min}$, after which it was stored in the dark for 30 min at room temperature. The percentage decolourisation was measured spectrophotometrically at $517 \mathrm{~nm}$ using the SPECTRAmax 340PC microtiter plate reader. The negative controls contained $20 \mu \mathrm{l}$ of plant extract to which $280 \mu \mathrm{l}$ of methanol was added, in the absence of DPPH and the positive controls were prepared using quercetin and emodin, to which $280 \mu \mathrm{l}$ of DPPH was added. The percentage decolourisation was then determined for each of the test samples (using equation 2.1), as a measure of the DPPH free radical scavenging activity.

The antioxidant activity is expressed as $50 \%$ effective concentration $\left(\mathrm{EC}_{50}\right)$, which is defined as the concentration (in $\mu \mathrm{g} / \mathrm{ml}$ ) of extract required to scavenge $50 \%$ of DPPH in reaction mixture. Percentage DPPH Scavenging Effect was plotted against the concentration of the sample and the $\mathrm{EC}_{50}$ values were determined.

\section{Equation 2.1}

DPPH Scavenging Effect $(\%)=[[\mathrm{Av}$ controls $-(\mathrm{Av}$ sample $_{\mathrm{DPPH}}-$ Av sample methanol $\left.\left._{1}\right)\right] /$ Av controls] $* 100$

Where:

Av controls = average absorbance of all DPPH control wells - average absorbance of all methanol control wells

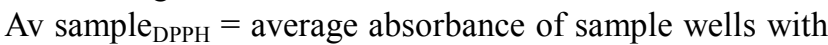
DPPH

Av sample $_{\text {methanol }}=$ average absorbance of sample wells with methanol

\subsection{Determination of Total Phenolic Contents}

Total phenolic constituents of the extracts were analyzed by Folin-Ciocalteu method using gallic acid as standard as described by Singleton, Orthofer \& Lamuela-Raventos (1999) with some modifications.

For the preparation of gallic acid stock solution, $50 \mathrm{mg}$ of dry gallic acid was dissolved in $1 \mathrm{~mL}$ of ethanol and diluted to $10 \mathrm{ml}$ with $\mathrm{ddH}_{2} \mathrm{O}$. Then the gallic acid stock solution was diluted with $\mathrm{ddH}_{2} \mathrm{O}$ at different concentrations, prepared as serial dilutions, ranging from 500 to $50 \mu \mathrm{g} / \mathrm{ml}$. The extracts $(3.5 \mu \mathrm{l})$ from a $1 \mathrm{mg} / \mathrm{ml}$ methanol stock solution or standard solutions of gallic acid $(3.5 \mu \mathrm{l})$ or $\mathrm{ddH}_{2} \mathrm{O}$ as blank were added to separate test tubes and mixed thoroughly with 276.5

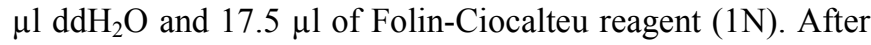
$8 \mathrm{~min} 52.5 \mu \mathrm{l}$ of $7 \% \mathrm{Na}_{2} \mathrm{CO}_{3}(0.66 \mathrm{M})$ solution was added, and mixed thoroughly by pipetting. The final concentration of the extracts in each well was $10 \mu \mathrm{g} / \mathrm{ml}$. The solutions were incubated at room temperature for $2 \mathrm{~h}$ and the absorbance versus blank ( $0 \mu \mathrm{g} / \mathrm{ml}$ gallic acid) was read at $765 \mathrm{~nm}$ using the SPECTRAmax 340PC microtiter plate reader.

The total phenol content of the extracts was determined by comparing with a calibration curve of the gallic acid standard 
and represented as mg gallic acid equivalents (GAE) /g of dried samples according to the equation obtained from the standard gallic acid graph.

\subsection{Determination of Total Flavonoid Contents}

The total flavonoid content in the extracts was determined by aluminium colorimetric assay (Zhishen, Mengcheng \& Jianming, 1999) with some modifications.

A standard solution of $(+)$ catechin at different concentrations $(20,40,60,80$ and $100 \mu \mathrm{g} / \mathrm{ml})$ was prepared by dissolving $(+)$ catechin in $\mathrm{ddH}_{2} \mathrm{O}$. The extracts $(35 \mu \mathrm{l})$ from a $1 \mathrm{mg} / \mathrm{ml}$ stock solution or standard $(+)$ catechin solutions ( $35 \mu \mathrm{l}$ ) or $\mathrm{dd}_{2} \mathrm{O}$ (as blank) were mixed thoroughly

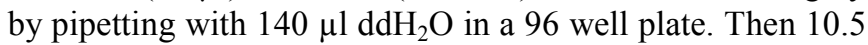
$\mu 1$ of $5 \% \mathrm{NaNO}_{2}$ was added. The mixture was incubated for 5 min at $25{ }^{\circ} \mathrm{C}$ and $10.5 \mu \mathrm{l}$ of $10 \% \mathrm{AlCl}_{3}$ was added to and then 6 min later, $70 \mu 11 \mathrm{M} \mathrm{NaOH}$ was added to the wells. The total volume was made up to $350 \mu$ by adding $\mathrm{ddH}_{2} \mathrm{O}$. The absorbance was read at $490 \mathrm{~nm}$ using the SPECTRAmax $340 \mathrm{PC}$ microtiter plate reader. $\mathrm{dd}_{2} \mathrm{O}$ was used as a blank.

The total flavonoid content was expressed as $\mathrm{mg}$ of catechin equivalents $(\mathrm{CE}) / \mathrm{g}$ of dried samples according to the equation obtained from the standard catechin graph.

\subsection{Cell Line and Culture Conditions}

HL-60 cells, a human promyeloblastic leukemia cell line, were grown in RPMI-1640 supplemented with $10 \%$ heatinactivated fetal bovine serum (FBS), $2 \mathrm{mM} 1$ - glutamine and $0.2 \%(50 \mathrm{mg} / \mathrm{ml})$ gentamicine in the vessels appropriate for the designed experiment. The cells were incubated at $37{ }^{\circ} \mathrm{C}$ with $95 \%$ air and $5 \% \mathrm{CO}_{2}$ in a Hepa filtered Heraeus Hera Cell 150 incubator. They were manipulated in a HERAsafe Class II Biological Safety (laminar flow) cabinet by using appropriate cell culture techniques. The medium was collected and refreshed every 2-3 days simulating usual cell culture conditions to maintain a constant cell to growth medium ratio.

\subsection{Measuring Viability of Cells using XTT Assay}

The effects of the Rheum ribes shoots and roots ethyl acetate extracts on the cytotoxicity of HL-60 cell line were evaluated by means of the Cell Proliferation Kit (Biological Industries, Israel) in 96 well flat bottomed microtiter plates.

Aliquots of $50 \mu \mathrm{l}$ of the $2 \times 10^{3}$ cells $/ \mathrm{ml}$ cell suspension were seeded into the 96-well plate. The plates were then incubated at $37{ }^{\circ} \mathrm{C}$ in $5 \% \mathrm{CO}_{2}$ for 12 hours to achieve the cell maintenance. No cells were seeded into the blank wells (instead, $100 \mu \mathrm{l}$ of experimental media was added). Plant extracts $(50 \mu \mathrm{l})$ were added in triplicate to the wells already containing $50 \mu \mathrm{l}$ of cell suspension. The controls comprised of: (i) DMSO in experimental media, $<0.1 \%$ (negative control), (ii) plant extract with experimental media in the absence of HL-60 cells (color control), (iii) experimental media in absence of both plant extract and HL-60 cells (blank control). Control wells aided in the determination of any background extract absorbance, especially in the event of colour interferences or interaction of the extract with the XTT solution. Each plate contained four wells for the blank cell-free control. At the end of the incubation time, $100 \mu \mathrm{L}$ of phenazine metho-sulfate is added to $5 \mathrm{ml}$ of XTT reagent, and $50 \mu 1$ of this XTT solution was added to each well before being incubated for a further 5 hours. Then, XTT reagent was applied to form a soluble dye. After incubation at $37^{\circ} \mathrm{C}$ for 5 $\mathrm{h}$, the dissolution of formazan crystals that were produced by mitochondrial enzymes of the living cells occurred, the optical density of chromogenic product was measured at 415 $\mathrm{nm}$ with a Spectromax 340 96-well plate reader (Molecular Devices, Sunnyvale, CA, USA). The results were expressed in terms of percentage cellular viability, calculated using equation 2.2, taking the relevant controls into account. The $\mathrm{IC}_{50}$ value for each sample was determined from a $\log$ sigmoid dose response curve generated. The assay was performed in triplicate.

$$
\% \text { Cell Viability }=\frac{A b s_{s(\text { with cell })}-A b s_{s(\text { cell free })}}{A b s_{c(\text { with cell })}-A b s_{c(\text { cell free })}} \times 100
$$

Where;

$A b s_{s(\text { withcell })} \quad=$ Average absorbance of cells treated with extracts

$A b s_{s(\text { cell free })} \quad=$ Average absorbance of extracts in cell free medium

$A b s_{c \text { (with cell })}=$ Average absorbance of untreated cells, control

$A b s_{\text {c(cell free })} \quad=$ Average absorbance of cell free medium

$A b s=$ Absorbance at $415 \mathrm{~nm}$

\subsection{Cell Observation using an Inverted Microscope}

Cell shrinkage, membrane blebbing and the formation of apoptotic bodies are characteristic events during apoptosis, which can be easily detected by light microscopy. HL-60 cells $\left(2 \times 10^{5}\right.$ cells $/ \mathrm{ml} ; 1 \mathrm{ml} /$ well; 24 -well plate $)$ were either left untreated or stimulated with $100 \mu \mathrm{g} / \mathrm{ml}$ ASE and ARE, for $72 \mathrm{~h}$. Cells were viewed at a 400-fold magnification with an inverted microscope. (Olympus CKX 41).

\subsection{Flow Cytometry Analysis}

The two modes of cell death, apoptosis and accidental cell death (necrosis), differ fundamentally in their morphology, biochemistry and biological relevance. In this part, to characterize and differentiate between two different mechanisms of cell death, apoptosis and necrosis flow cytometry was used.

Detection of apoptosis using Annexin V after Rheum ribes treatment was performed using an APC- labeled Recombinant Human Annexin V and 7AAD antibody. Annexin V-Apc ( $\lambda$ ex: 633, $\lambda$ em: $660 \mathrm{~nm})$ is detected in FL4 on dual laser instruments and 7AAD ( $\lambda$ ex: $488, \lambda$ em: $647 \mathrm{~nm}$ ) is detected in FL3 channel on most instruments.

All measurements were performed on a FACScalibur (BD 
Biosciences, Palo Alto, CA, USA), equipped with a $488 \mathrm{~nm}$ argon-ion laser, using CellQuest ${ }^{\mathrm{TM}}$ software. Analysis was investigated using FlowJo software (Treestar, Ashland, OR, USA).

HL-60 cells $\left(2.5 \times 10^{5}\right.$ cells $/ \mathrm{ml} ; 1 \mathrm{ml}$; 24 -well plate $)$ were either left untreated or treated with a concentration range of Rheum ribes freeze-dried extracts for 24, 48 and $72 \mathrm{~h}$. Cells were harvested by centrifugation ( $500 \times \mathrm{x}, 5 \mathrm{~min}, \mathrm{RT})$, washed with cold PBS, resuspended in a volume of $500 \mu 1$ cold PBS and incubated with 1X Annexin V-apc (50x) solution and $1 \mathrm{X} 7 \mathrm{AAD}(100 \mathrm{x})$ solution for $15 \mathrm{~min}$ at room temperature, $25{ }^{\circ} \mathrm{C}$ in dark room. After centrifugation $(500 \mathrm{x}$ $g, 5 \mathrm{~min}, \mathrm{RT}$ ) the cells was washed twice with $1000 \mu \mathrm{l}$ PBS (Biochrom L 1825) and then obtained cell pellet was resuspended with $500 \mu \mathrm{l}$ PBS. The samples were immediately analyzed by flow cytometry.

It was important to have separate and distinctive populations. In these populations; (i) cells that stained positive for Annexin V-apc and negative for 7-AAD were undergoing apoptosis, (ii) cells that stain positive for both Annexin $\mathrm{V}$-apc and 7-AAD were either in the end stage of apoptosis which were undergoing necrosis, or were already dead, (iii) cells that stain negative for both Annexin V-apc and 7-AAD were alive and not undergoing measurable apoptosis.

\subsection{Statistical Analysis}

All experiments were performed in triplicate unless otherwise noted; results are expressed as mean \pm standard deviation. Data analysis and graphing was performed using the GraphPad Prism version 5 (GraphPad Software, San Diego, California, USA). For all the measurements, oneway ANOVA followed by Tukey's Multiple Comparison Test was used to assess the statistical significance of difference between control and Rheum ribes extract-treated groups in vitro. A statistically significant difference was considered to be at $p<0.05$.

\section{Results and Discussion}

\subsection{Determination of Antioxidant Capacities of Rheum ribes}

Relatively stable radicals such as DPPH are often preferred in the assessment of radical scavenging activity. This radical has been widely used in various studies of plant extracts and foods (Koleva 2002; Lee, 2003). The popularity of using the DPPH free radical method for estimating free radical scavenging activity may be due to its simple, rapid and economic properties. In our study, DPPH radical scavenging activity of extracts prepared by ethyl acetate extraction was monitored at $517 \mathrm{~nm}$ for 30 minutes.

The Radical Scavenging Activity (RSA) of each extract was calculated and used for determination of $\mathrm{EC}_{50}$ values, which indicated the amount of the extract scavenging $50 \%$ of DPPH radical. As shown in Figure 3.1 the antioxidant capacities ( $\%$ RSA) in both samples increased in a concentration dependent manner up to a certain extract concentration, and then reached a plateau.

The DPPH radical scavenging capacity which was expressed as $\mathrm{EC}_{50}$ was obtained in ARE with $10.92 \pm 0.21$ $\mu \mathrm{g} / \mathrm{ml}$ and $96.67 \pm 0.98$ is higher than obtained in ASE with $206.28 \pm 10.21 \mu \mathrm{g} / \mathrm{ml} \mathrm{EC}_{50}$ value, which was also exhibited maximum $80.34 \pm 0.98 \%$ scavenging potential as shown in the Figure 3.1 and Table 3.1. This difference obtained between the shoot and root residue with ethyl acetate extraction could be due to presence of less phenolic constitutes in the ASE than ARE.

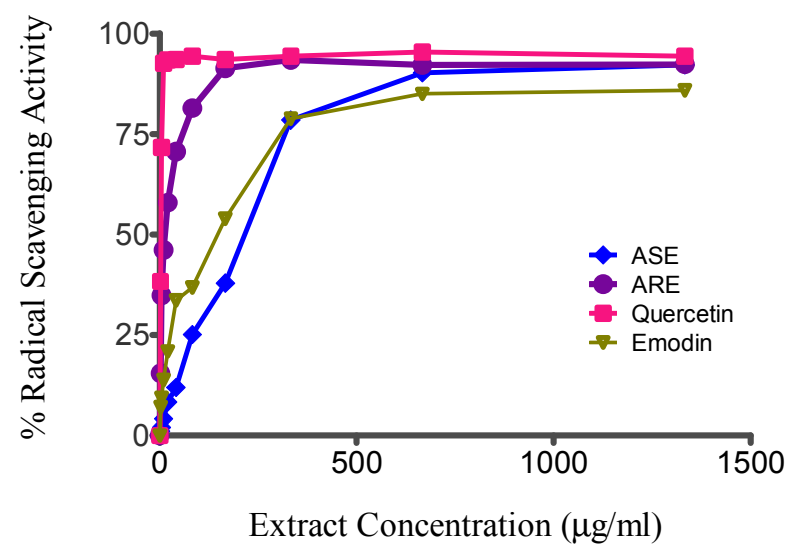

Figure 3.1. Percent DPPH scavenging activities (\% RSA) of Rheum ribes shoot and root extracts prepared in ethyl acetate (EtOAc) and the reference materials. Each point is the mean of quadruple measurements from three different sets of experiments $(n=3)(* p<0.05$ compared to and analyzed by one way ANOVA).

As compared to result of the present study, Ozturk et al., 2007 observed higher antioxidant activity with methanol extract of Rheum ribes shoots, however they obtained lower antioxidant activity with methanol root, chloroform shoot and root extracts. This could be due to the difference at applied time and temperature during extraction (Ozturk, 2007).

DPPH radical scavenging capacities of reference materials such as quercetin and emodin were also determined since they were quite often used in the literature as phenolic standards, and displayed in the Figure 3.1. Besides, emodin was one of the anthraquinones found in Rheum ribes (Tosun, 2003). ARE showed greater antioxidant activity than emodin and almost the same activity to that of quercetin.

\subsection{Determination of Total Phenol and Total Flavonoids}

Total phenolic and flavonoid contents of Rheum ribes extracts were determined by the method of Singleton and Rossi (1965), the Folin-Ciocalteu reagent assay (FC) and the aluminium colorimetric assay (Whiten, 1999), respectively.

Total phenolic compounds were determined as $\mathrm{mg}$ equivalents of gallic acid per $g$ of crude extracts and total flavonoid compounds were determined as $\mathrm{mg}$ equivalents of catechin per $g$ of crude extracts given in the Table 3.1

Ethyl acetate extraction of root presented the higher total phenolic and flavonoid contents than shoot. 
Table 3.1. Summary of antioxidant activity, contents of Total phenol and flavonoid in the ethyl acetate extracts of Rheum ribes GAE: Gallic Acid Equivalents CAE: Catechin Equivalents.

\begin{tabular}{|c|c|c|c|c|}
\hline Samples & $\begin{array}{l}\text { Antioxidant Activity } \\
\left(\mathrm{EC}_{50} \mu \mathrm{g} / \mathrm{ml} \pm \mathrm{SD}^{\propto p}\right)\end{array}$ & $\begin{array}{c}\text { Maximum \% Radical Scavenging } \\
\text { Activity }\left(\% \mathrm{RSA} \pm \mathrm{SD}^{\wp}\right)\end{array}$ & $\begin{array}{c}\text { Total Phenol (mg GAE/g dried } \\
\left.\text { extract } \pm \mathrm{SD}^{\wp}\right)\end{array}$ & $\begin{array}{c}\text { Total Flavonoid (mg CAE/g } \\
\left.\text { dried extract } \pm \text { SD }^{\wp}\right)\end{array}$ \\
\hline ASE & $206.28 \pm 10.21$ & $80.34 \pm 0.98$ & $21.11 \pm 1.11$ & $2.29 \pm 1.04$ \\
\hline ARE & $10.92 \pm 0.21$ & $96.67 \pm 0.98$ & $207.22 \pm 6.96 .72$ & $50.49 \pm 2.03$ \\
\hline Emodin & $164.30 \pm 23.13$ & $85.98 \pm 1.47$ & NA & NA \\
\hline Quercetin & $4.49 \pm 2.54$ & $95.39 \pm 1.96$ & NA & NA \\
\hline
\end{tabular}

TP GAE : Total phenolic contents mg equivalents of gallic acid/g of plant extract, TF CAE : Total flavonid contents mg equivalents of catechin/g of plant extract, ND: not detected, NA: not applicable, ${ }^{\mathrm{r}} \mathrm{SD}$ : was derived from three independent experiments.

As known, there is a significant linear correlation between phenolic concentration and free radical scavenging activity and flavonoids are natural phenolic compounds and well known antioxidants. In this study, antioxidant activity of root extracts extracted in ethyl acetate was found to be fairly higher which are also rich in flavonoids.

From the chemical analysis of Rheum ribes extracts; ASE was the lower effective extract. Shoot extract with lower polarity had lower antioxidative activity with lower phenolic flavonoid content.

\subsection{Cytotoxicity of Rheum ribes Shoot and Root Extracts in HL-60 Cells}

\subsubsection{Light Microscopic Analysis of Cell Morphology}

For the investigation of cytotoxic effects of Rheum ribes extracts, morphological criteria were combined with commonly accepted biochemical methods. The effects of Rheum ribes on morphological changes and viability in HL60 cells treated for $48 \mathrm{~h}$ were analyzed under light inverted microscope (magnification, 400X) as shown in Figure 3.2. HL-60 cells $\left(2 \times 10^{5}\right.$ cells $/ \mathrm{ml} ; 1 \mathrm{ml} /$ well; 24 -well plate) were either left untreated or treated with $100 \mu \mathrm{g} / \mathrm{ml}$ ASE and ARE for $48 \mathrm{~h}$.
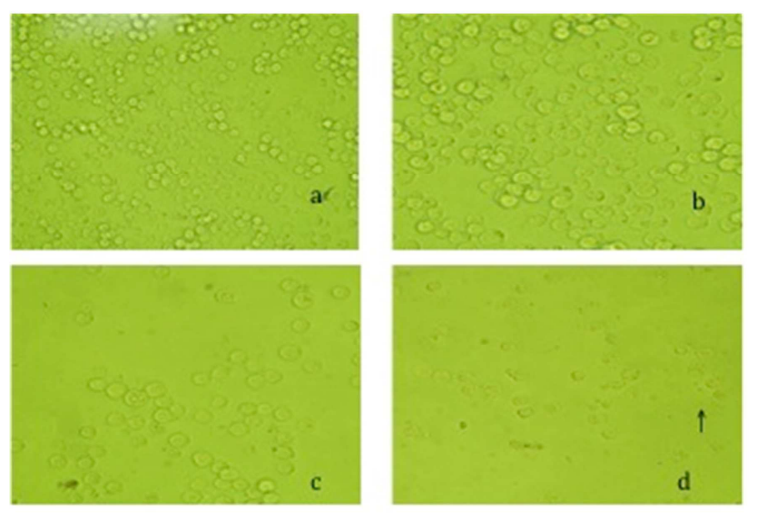

Figure 3.2. Light Microscopic Analysis of effects of Rheum ribes Extracts on morphological changes in HL-60 cells for $48 \mathrm{~h}$. (a) Un-treated cell; (b) DMSO \% 0.1, $100 \mu \mathrm{g} / \mathrm{ml}$ of (c) ASE and (d) ARE; Arrow (d) indicates a typical apoptotic cell with apoptotic body. The cells were photographed under inverted light microscopy (magnification, 400X).
The HL-60 cells grow in single cell suspension without any tendency to clump or to adhere to plastic or glass (Fig 3.2 a) with a round or ovoid shape, and occasional cells have blunt pseudo pods. After incubation with ASE and ARE alterations and cell growth inhibition in HL-60 cells were illustrated comparing with control and DMSO treated cells (Fig $3.2 \mathrm{a}$ and b). Control or DMSO treated cells were round in normal shape. Exposure of HL-60 cells to those ARE for $48 \mathrm{~h}$ led to the membrane blebbing and apoptotic body formation (Fig $3.2 \mathrm{~d}$ ) which were observed by light inverted microscope $(400 \mathrm{X})$.

At $100 \mu \mathrm{g} / \mathrm{ml}$ concentration, cell growth ratio was decreased significantly higher by ARE than ASE for 48 hin microscopic analysis.

\subsubsection{XTT Assay}
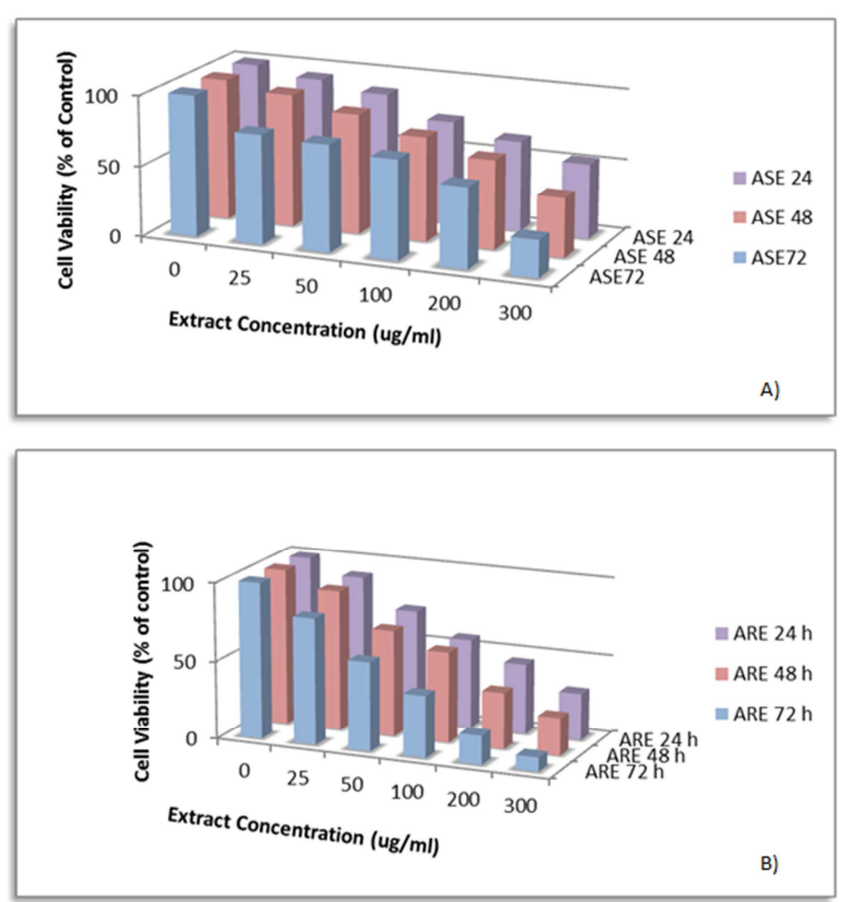

Figure 3.3. Effects of Rheum ribes shoot (A) and root (B) ethyl acetate extract on cell survival in HL-60 cells. Cytotoxicity was measured by the XTT assay.. The percentage of cell growth in the control group was designated as $100 \%$. 
Metabolically active HL-60 cells were detected using XTT assay upon treatment with Rheum ribes extracts for 24, 48 and 72 hours. Mitochondrial enzymes of the metabolically active cells reduced tetrazolium salt; XTT to orange colored formazan product was measured using ELISA plate reader. Cell viability measurements obtained from XTT assay were converted to percent cell viability by setting control $(0.1 \%$ DMSO) results as $100 \%$ cell viable. HL-60 cells were precultured in 96-well microplates for $12 \mathrm{~h}$ and then incubated with $0-300 \mu \mathrm{g} / \mathrm{ml}$ of Rheum ribes shoot and root ethyl acetate extract for 24,48 and $72 \mathrm{~h}$. \% cell viability for different time points $(0,24,48$ and $72 \mathrm{~h})$ versus different Rheum ribes extracts concentrations $3 \mathrm{D}$ column graph were constructed (Figure 3.3). The $\mathrm{IC}_{50}$ values were determined using GraphPad Prism version 5 for Mac OS X as shown in Table 3.2.

$\mathrm{IC}_{50}$ values that were the Rheum ribes extracts concentrations at which $50 \%$ of cells are viable were calculated as $288 \mu \mathrm{g} / \mathrm{ml}, 252 \mu \mathrm{g} / \mathrm{ml}$ and $192 \mu \mathrm{g} / \mathrm{ml}$ after ASE treatment for 24,48 and $72 \mathrm{~h}$, respectively. The results were not statistically significant for all time points. ASE had growth inhibitory effects; however ASE cytotoxicity was not occurred at a time dependent manner in HL-60 cells.

$\mathrm{IC}_{50}$ values were calculated as $149 \mu \mathrm{g} / \mathrm{ml}, 135 \mu \mathrm{g} / \mathrm{ml}$ and $74 \mu \mathrm{g} / \mathrm{ml}$ after ARE treatment for 24,48 and $72 \mathrm{~h}$, respectively. The results were not statistically significant for 24 and $48 \mathrm{~h}$, however for $72 \mathrm{~h}$ cells viability dropped dramatically.

Table 3.2. Comparison of $I C_{50}$ values in HL-60 cells obtained by XTT Assay after treatment of Rheum ribes for 24, 48 and $72 \mathrm{~h}$.

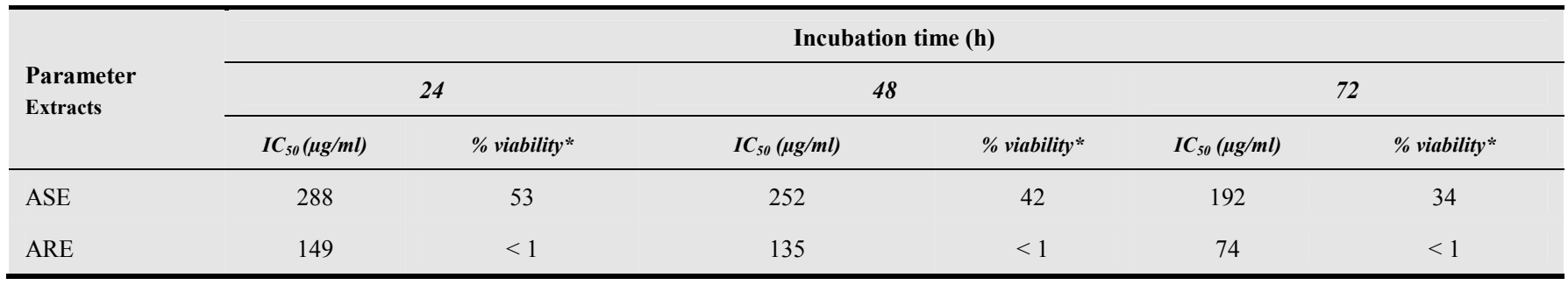

*\% viability was calculated considering the viable cell count at highest extract concentration $(500 \mu \mathrm{g} / \mathrm{mL})$ compared to control viable cell count at every incubation time point NA: not applicable

These results showed that the difference between the $\mathrm{IC}_{50}$ values of ASE and ARE in HL-60 cells was statistically significant, $\mathrm{p}<0.05$ and the growth inhibitory effect of ARE was higher than ASE in HL-60 cells for all time points, because the amount of extract concentration required to inhibit $50 \%$ metabolic activity of the cells were significantly low.

According to the criteria established by the U.S. National Cancer Institute (NCI), the compounds with $\mathrm{IC}_{50}<30 \mu \mathrm{g} / \mathrm{ml}$, $30 \mu \mathrm{g} / \mathrm{ml}<\mathrm{IC}_{50}<100 \mu \mathrm{g} / \mathrm{ml}$ and $\mathrm{IC}_{50}>100 \mu \mathrm{g} / \mathrm{ml}$ are judged as active, moderately active and inactive, respectively (Suffness, 1990). ARE exhibited the highest activity and showed moderate cytotoxicity with $\mathrm{IC}_{50}$ (calculated from TBA assay) $<100 \mu \mathrm{g} / \mathrm{ml}$ that fall within the NCI criteria. ASE shows some cytotoxicity, however those were judged as inactive according to NCI criterion for $72 \mathrm{~h}$.

Biological activity studies were carried out using HL-60 cells. Rheum ribes extract prepared in ethyl acetate was applied at different concentrations for 24,48 and $72 \mathrm{~h}$ to the feeding environment of the cells. As a conclusion, ARE had the highest potential with lower $\mathrm{IC}_{50}$ for all time points from the obtained results of XTT assay.

\subsection{Detection of Phosphatidylserine Translocated to the Cell Surface}

Rheum ribes treatment led to the exposure of phosphatidylserine (PS) on the outside of the plasma membrane, a characteristic event in early stages of apoptosis, detected by Annexin V-apc staining and FACS analysis . Costaining with 7AAD allowed discrimination between apoptotic and necrotic cells.

Cells were treated with ASE and ARE at concentrations of 100 and $250 \mu \mathrm{g} / \mathrm{ml}$ for $72 \mathrm{~h}$. After treatment, cells were stained with annexin V/7AAD and analyzed by flow cytometry. Cells treated with $0.1 \%$ DMSO was used as control. 

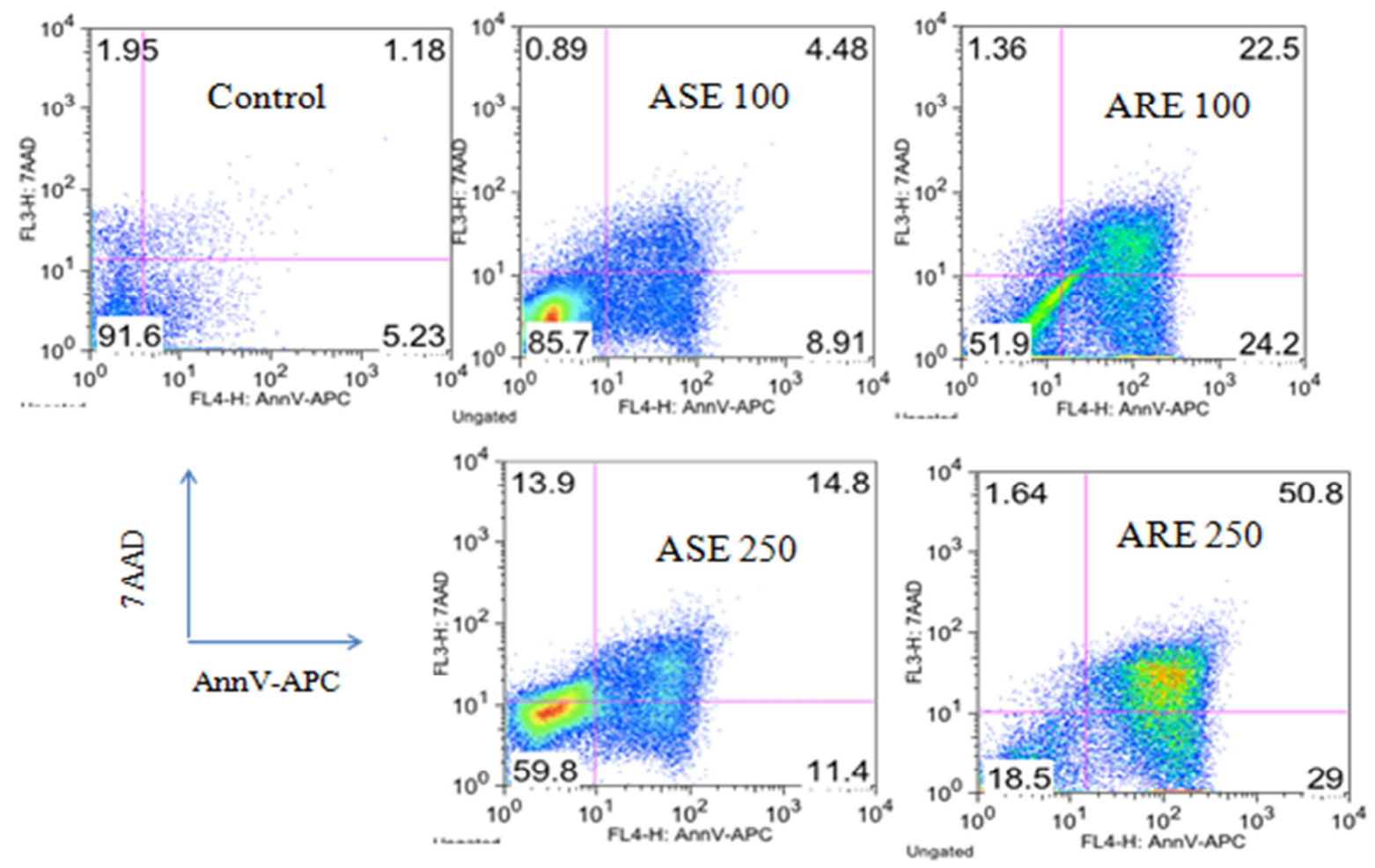

Figure 3.4. Cell apoptosis, percentage of HL-60 cells after treatment with ASE and ARE by flow cytometric analysis for $72 \mathrm{~h}$.

These results demonstrated that there was a dosedependent fashion in annexin V/7ADD double positive cells induced by ASE and ARE as shown in Figure 3.4 and Table 3.3. At $72 \mathrm{~h}$, the observed maximal apoptosis was about $42 \%$ for ASE and $81 \%$ for ARE at the concentration of $250 \mu \mathrm{g} / \mathrm{ml}$. Apoptosis in response to ARE was early, whereas apoptosis in response to ASE was significantly late.

In apoptosis induced by ASE for $72 \mathrm{~h}$, PS externalization occurred as the same time as disruption of membrane integrity. This was a result of presence of early and late apoptotic components in the ASE.

The apoptosis induced by ARE of $100 \mu \mathrm{g} / \mathrm{ml}$ for $72 \mathrm{~h}$ was dominantly PS externalization, however by ARE of 250 $\mu \mathrm{g} / \mathrm{ml}$, dominant cell death was late apoptosis or necrosis which was a result of disruption of membrane integrity. This result showed that the components found in ARE were generally shown characteristics of early apoptotic agents.

There are other reports indicating the effects of Rheum species on apoptosis in several cell lines. In human cervical $\mathrm{Bu} 25 \mathrm{TK}$ cancer cells and human lung squamous carcinoma $\mathrm{CH} 27$ cells, emodin induced apoptosis through mitochondrial activation of caspase 3 and 9 and with Bax upregulation (Srinivas et al., 2003; Lee, 2001).

\section{Conclusions}

Considering all the results obtained in the present study, Rheum ribes could be considered as a dietary antioxidant and anticancer agent. Our investigations for the pursuit of these interactions may not result in hundred percent prevention or in total cure of leukemia, but this was a rational way forward, to catch on to the cutting-edge technologies.

\section{Acknowledgements}

This study was supported by the Research Fund of METU ÖYP Grant No: BAP-08-11-DPT-2002K120510. The authors are also grateful to botanist Assoc. Prof. Dr. Fevzi Özgökçe for collecting plant samples and his collaboration.

\section{References}

[1] Abu-Irmaileh, B. E., \& Afifi, F. U. (2003). Herbal medicine in Jordan with special emphasis on commonly used herbs. Journal of Ethnopharmacology, 89, 193-197.

[2] Awika, J. M., Rooney, L. W., \& Waniska, R. D. (2005). Anthocyanins from black sorghum and their antioxidant properties. Food Chemistry, 90, 293-301.

[3] Baydar, N. G., Ozkan, G., \& Sagdic, O. (2004). Total phenolic contents and antibacterial activities of grape (Vitis vinifera L.) extracts. Food Chemistry, 15, 335-339.

[4] Baytop, T. (1999). Rheum ribes L. In T. Baytop (Ed.). Therapy with medicinal plants in Turkey, Nobel Tip Publication Press, 1, pp. 319-320).

[5] Blois, M.S., (1958). Antioxidant determinations by use of a stable free radical. Nature, 181, 1199-1200 .

[6] Cai, Y., Sun, M., Xing, J., \& Corke, H. (2004). Antioxidant phenolic constituents in roots of Rheum officinale and Rubia cordifolia: structure-radical scavenging activity relationships. Journal of Agricultural Food Chemistry, 52, 7884-7890. 
[7] Castañeda-Ovando, A., de Lourdes Pacheco-Hernández, Ma, Elena, Ma, Páez- Hernández, J. A., RodríguezGalán-Vidal, J. A., \& Galán-Vidal, C. A. (2009). Chemical studies of anthocyanins: A review. Food Chemistry, 113, 859-871.

[8] Collins, S.J., (1987). "The HL-60 promyelocytic leukemia cell line: proliferation, differentiation, and cellular oncogene expression”, Blood, Vol 70, 1233-1244.

[9] Cullen, J. (1966). Rheum L. In PH. Davis (Ed.). Flora of Turkey and the East Aegean Islands. Edinburgh: Edinburgh University Press, 2, 268-269.

[10] Enayat, S,. Banerjee., S., 2009. Comparative antioxidant activity of extracts from leaves, bark and catkins of Salix aegyptiaca sp. Food Chemistry, Vol 116, 23-28

[11] Fadok, V. A., Voelker, D.R., Campbell, P.A., Cohen, J.J., Bratton, D.L., Henson, P.M., (1992). "Exposure of phosphatidylserine on the surface of apoptotic lymphocytes triggers specific recognition and removal by macrophages", Journal of Immunology, 148, 2207-2216.

[12] Freshney, R. I., (2005). "Culture of Animal Cell: A manual of Basic Technique", (5 $5^{\text {th }}$ Edition).

[13] Gulcin, I., Oktay, M., Kirecci, E., \& Kurevioglu, O. _I. (2003). Screening of antioxidant and antimicrobial activities of anise (Pimpinella anisum L.) seed extracts. Food Chemistry, 83, 371-382.

[14] Hollman, P. C. H., \& Katan, M. B. (1999). Dietary flavonoids: Intake, health effects and bioavailability. Food and Chemical Toxicology, 37, 937-942.

[15] Kashiwada, Y., Nonaka, G., Nishioka, I., \& Yamagishi, T. (1988). Galloyl and hydroxycinnamoyl glucoses from Rhubarb. Phytochemistry, 27, 1473-1477.

[16] Lapornik, B., Prosek, M., \& Golc, Wondra. A. (2005). Comparison of extracts prepared from plant by-products us ing different solvents and extraction time. Journal of Food Engineering, 71, 214-222.

[17] Li, P., Nijhawan, D., Budihardjo, I., Srinivasula, S.M., Ahmad, M., Alnemri, E.S. and Wang, X., 1997. "Cytochrome c and dATP-dependent formation of Apaf-1/caspase-9 complex initiates an apoptotic protease cascade", Cell, Vol 91, 479-489.

[18] Liu, Q., Cai, W., \& Shao, X. (2008). Determination of seven polyphenols in water by high performance liquid chromatography combined with preconcentration. Talanta, 77, 679-683.
[19] Mericli, A. H., \& Tuzlac1, E. (1990). Constituents of Rheum ribes. Fitoterapia, 61, 375.

[20] Özbek, H., Ceylan, E., Kara, M., Özgökce, F., \& Koyuncu, M. (2004). Hypoglycemic effect of Rheum ribes roots in alloxan induced diabetic and normal mice. Scandinavian Journal of Laboratory Animal Science, 31, 113-115.

[21] Ozgokce F, Ozcelik H (2004). Ethnobotanical aspects of some taxa in East Anatolia (Turkey), Econ. Bot. 58: 697-704.

[22] Ozturk M., F. Aydogmus-Ozturk, M.E. Duru and G. Topcu, Antioxidant activity of stem and root extracts of Rhubarb (Rheum ribes) An edible medicinal plant, Food Chem 103 (2007), 623-630

[23] Shokravi, A., \& Agha Nasiri, K. (1997). Synthesis of 1,2,3,4,5,6,7,8- Octahydro-9-ethoxy-10-hydroxy-1anthracenone (OEHA). Iranian Journal of Chemistry and Chemical Engineering, 16, 10-15.

[24] Singleton, R. Orthofer and R.M. Lamuela-Raventos, Analysis of total phenols and other oxidation substrates and antioxidants by means of Folin-Ciocalteu reagent, Oxidants and Antioxidants

[25] Tabata, M., Sezik, E., Honda, G., Yesilada, E., Fuki, H., Goto, K., et al. (1994). Traditional medicine in Turkey III. Folk Medicine in East Anatolica, Van and Bitlis provinces. International Journal of Pharmacognosy, 32, 3-12.

[26] Tosun, F., \& Akyuz-Kızılay, C. (2003). Anthraquinones and flavonoids from Rheum ribes. Journal of Faculty of Pharmacy Ankara, 32, 31-35.

[27] Tsao, R., \& Yang, R. (2003). Optimization of a new mobile phase to know the complex and real polyphenolic composition: Towards a total phenolic index using high-performance liquid chromatography. Journal of Chromatography A, 1018, 29-40.

[28] Tuzlaci, E., \& Mericli, A. H. (1992). Some studies on Is kın (Rheum ribes) and its distribution in Turkey. Proceedings of the 9th symposium on plant drugs (Pub No. 641, pp. 336-341). Eskis ehir, Turkey: Anatolia University Press.

[29] Yesilada E, Sezik E, Honda G, Takaishi Y, Takeda Y, Tanaka T (1999). Traditional medicine in Turkey IX. Folk medicine in north-west Anatolia. J. Ethnopharmacol. 64: 195-210.

[30] Zhishen, T. Mengcheng and W. Jianming, The determination of flavonoid contents in mulberry and their scavenging effects on superoxide radicals, Food Chemistry 64 (4) (1999), 555559 . 